\title{
Berotec, Depakene e Zodel: ambiguidades farmacológicas no contexto da Síndrome Congênita do Vírus Zika em Recife/PE
}

\author{
SORAYA FLEISCHER \\ UNIVERSIDADE DE BRASÍLIA (UNB), BRASÍLIA/DF, BRASIL \\ HTTPS://ORCID.ORG/OOOO-0002-76I4-I382
}

ANA CLAUDIA DE CAMARGO

UNIVERSIDADE FEDERAL DE SANTA CATARINA (UFSC), FLORIANÓPOLIS/SC, BRASIL

HTTPS://ORCID.ORG/OOOO-OOOI-5264-3655

\section{Introdução: a decoração hospitalar}

Os consultórios que conhecemos, ao acompanhar nossas interlocutoras e seus filhos e filhas, ficavam geralmente nos grandes hospitais públicos e a decoração se resumia a um mobiliário com cadeiras, mesa e maca, um calendário de papel e itens de escritório, talvez um pequeno armário onde ficassem guardadas as amostras grátis de medicamentos ${ }^{1}$. Tudo era simples, metálico e cinza. Em um consultório, contudo, notamos um quadro, preso à parede ao lado da cadeira da médica. O desenho antigo, desbotado e com um estilo dos anos 1990 retratava um festejo natalino. No centro, havia uma alta árvore de Natal, muitas crianças ao seu redor, um Papai Noel vindo com um grande saco de presentes. Todos pareciam muito felizes. Junto aos presentes, embaixo da árvore, havia uma bisnaga de um medicamento alopático pediátrico. Em meio a pacotes e embrulhos em formato de bicicleta, bola e boneca, havia

1 Esse texto foi produzido no âmbito do projeto de pesquisa "Síndrome congênita do vírus Zika em Recife/PE: Uma antropologia dos ímpetos maternos, científicos e políticos”, que conta com o apoio da Universidade de Brasília e do CNPq, no Brasil, e da Fundação Newton, na Inglaterra. Aproveitamos para agradecer às mulheres e suas crianças e famílias que tão generosamente nos aceitaram em suas casas, bairros e serviços de saúde, assistência e educação por onde circulam ao redor da grande Recife. Nossa equipe de pesquisa e o Coletivo de Antropologia e Saúde Coletiva (CASCA), ambos da UnB, também têm gentilmente acolhido e comentado criticamente nossas reflexões. 
uma empresa farmacêutica fazendo propaganda. Medicamentos e brinquedos, lado a lado, ornavam o cenário hospitalar daquele consultório frequentado pelas crianças.

A SCVZ, como se convencionou chamar a síndrome congênita decorrente da infecção pelo vírus Zika, é uma condição de saúde que reúne muitos sintomas e graus de deficiência nas crianças, com a possibilidade de desenvolverem complicações neurológicas, motoras, deglutivas e respiratórias. O nascimento de crianças com a SCZV foi a maior repercussão reprodutiva dos dois grandes surtos do vírus Zika no estado de Pernambuco, nos verões de 2015 e 2016. O Nordeste, em especial os estados de Pernambuco e da Bahia, foi a região do Brasil mais atingida pelo vírus e, consequentemente, com maior número de casos notificados de crianças nascidas com a síndrome (Diniz, 2016). Dada a intensidade epidemiológica, foi considerado, pelo Ministério da Saúde, como uma Emergência em Saúde Pública de Importância Nacional (ESPIN) entre 2016 e 2017 (Brasil, 2017), o que facilitou e acelerou um conjunto de ações voltadas para as crianças, cuidadoras, gestoras e instituições de apoio. Até o momento, consideram-se cerca de quatro mil casos confirmados de SCVZ no país (Brasil, 2019). Ainda que o contexto clínico varie pelas especificidades de cada criança (Valim, 2017), vez ou outra, podem ocorrer episódios pontuais com o agravamento de algum dos sintomas, episódios conhecidos pelas mães como "crises". As crises mais comuns vividas por essas crianças são as convulsivas e respiratórias, que podem necessitar de hospitalização e cuidado intensivo. É esse cenário que apresenta às mães, as principais cuidadoras, a necessidade de recorrer marcadamente a serviços de saúde, como o consultório que apresentamos acima.

Dentre esses serviços, estão principalmente consultas, exames, terapias reabilitadoras e medicamentos (Alves \& Fleischer, 2019; Fleischer, 2018, 2017; Scott, Lira, Matos, Souza, Silva \& Quadros, 2018). As crianças com a SCVZ exigem cuidados de especialistas, principalmente pediatras, neurologistas, pneumologistas, endocrinologistas, gastroenterologistas, oftalmologistas, terapeutas ocupacionais, fonoaudiólogos e fisioterapeutas. Com o primeiro grupo, a interação era na forma de consultas trimestrais de acompanhamento, amparada por exames clínicos, laboratoriais, radiológicos e ressonânticos. Com as últimas três especialidades, os encontros eram semanais e muito mais frequentes, em sessões de terapia de reabilitação sobre tatames, em consultórios, dentro de piscinas. A oferta de todos esses serviços e profissionais da saúde não era muito ampla no Recife, mas tendeu a aumentar e/ou se reorganizar com a chegada intensificada dessas crianças a partir de 2015. Com o fim da ESPIN e com o fim do período epidêmico, ambos em 2017, vimos as vagas e instituições públicas e também privadas paulatinamente se retraírem, sem, contudo, haver uma aguerrida resistência e crítica por parte das mães, famílias e associações comunitárias que lhes representavam.

Dentre todos esses serviços, tecnologias e insumos, ao longo dos quatro anos de convivência de nossa equipe de pesquisadoras com essas pessoas e cenários no Recife, entre 2016 e 2019, notamos a presença constante dos medicamentos e, nesse artigo, seguindo uma antropologia que lhes percebe, reconhece e problematiza (Whyte \& Geest, 2002; Geest \& Whyte, 2011; Fleischer, 2012; Castro, 2012; Camargo, 2021), optamos pelo foco nesses pequenos objetos. Whyte e Geest (2011) mostraram, a partir de uma rica comparação entre várias etnografias de medicamentos, como sua dimensão diminuta contribui para o uso, importância, circulação e potência desse objeto específico. Como o objetivo mais 
amplo de nossa pesquisa é acompanhar e conhecer as consequências a longo prazo que uma epidemia deixa, os medicamentos, que continuam sendo intensamente consumidos, têm se revelado uma boa pista etnográfica.

Quando essas mulheres nos convidavam para lhes visitar, no tradicional tour pela casa, era comum nos mostrarem onde ficavam os medicamentos. "O guarda-roupa do meu filho é um guarda-roupa de remédios", disse uma. "Tenho duas prateleiras só de remédio dele no meu armário", explicou outra. "Se você abrir o armário do meu filho, só tem remédio", contou uma terceira². Quartos, banheiros, cozinhas e até as salas de estar tinham espaços reservados aos medicamentos. Na casa de uma de nossas interlocutoras mais próximas, sobre o rack que ficava na sala, havia uma televisão plana, alguns porta-retratos e um enorme tupperware, com $50 \mathrm{~cm}$ de altura e $70 \mathrm{~cm}$ de profundidade, que guardava os medicamentos da filha. Medicamentos tinham se tornado objetos familiares para essas cuidadoras, visíveis e espalhados por todo canto da casa, e transportados para todo lugar por onde precisassem ir com os filhos, netos e sobrinhos com a SCVZ.

Os medicamentos também eram parte do figurino dessas mães e crianças. Como muitas passavam grande parte do dia circulando por dezenas e dezenas de quilômetros ao redor da cidade - para estarem com seus filhos em consultas, exames, reuniões, farmácias e creches -, precisavam levar nas mochilas tudo que fosse necessário para garantir o bem-estar da dupla, mãe e filho/a. Levavam a tiracolo não apenas a criança, que ainda não caminhava e precisava ser carregada, mas também bolsas pesadas com uma variedade de itens, como diferentes caixas, cartelas e ampolas de medicamentos, toda sorte de aparatos para dosar e administrá-los, como canequinhas, colheres, seringas, equipos, copinhos, medidores etc., e as respectivas receitas médicas com suas posologias específicas. Dentre os itens necessários nos cuidados diários de uma criança com SCVZ, anotamos muitos tipos de medicamentos utilizados: nebulização, suplementos vitamínicos, relaxantes musculares, antiespasmódicos, antibióticos, analgésicos, antitérmicos, hormônios, colírios, antidepressivos, laxantes, antidisfágicos, antigástricos, calmantes, entre outros. Nas mochilas também era comum encontrar fármacos utilizados pelas mulheres, muitas vezes para dar conta das dores lombares, nervoso, angústia e preocupação, além de cansaço, sono, refluxo e gastrite.

A infância com uma condição de saúde tão aguda como a SCVZ é perpassada intensamente pela biomedicina e suas tecnologias, em especial os medicamentos. Em consonância com o quadro que descrevemos no consultório médico, parece que, ao lado de presentes, árvore de Natal e Papai Noel, os medicamentos compõem intensa, mas discretamente a cena da infância. Mas os medicamentos não eram aceitos e administrados natural e automaticamente pelas mães dessas crianças da micro - vocativo polissêmico, intensamente presente no cenário da SCZV e muito caro a essas famílias ${ }^{3}$. Como desejamos aqui mostrar, elas foram sendo paulatinamente apresentadas aos diferentes itens, desconhecidos até então para muitas, e foram avaliando criticamente a eficácia e o consumo de cada um deles. A partir de uma maior compreensão sobre a SCVZ e sobre os serviços de saúde e seus profissionais, os medicamentos foram sendo absorvidos, física e simbolicamente, mas, pelo que temos notado, em um registro

2 Por enquanto, vamos usar de modo intercambiável "fármaco", "remédio" e "medicamento".

3 Para ver mais sobre a importância do termo "micro" no cenário da SCZV, ver Fleischer (2020). 
cada vez menos passivo e cada vez mais ambíguo. Uma coisa era esses medicamentos estarem presentes no contexto dessas infâncias, outra coisa era conviver com eles de modo totalmente resignado ou apaziguado - dois cenários bem diferentes, mas que transcorriam paralelamente, muitas vezes.

Ao pretendermos pensar a SCVZ a partir de uma de suas facetas mais recorrentes e controversas, nada mais adequado do que localizar os medicamentos no centro da narrativa etnográfica. Escolhemos três medicamentos, dentre os mais citados e usados por todas as famílias que conhecemos. Esses medicamentos - Berotec, Depakene e Zodel - servirão para apresentarmos algumas das famílias que conhecemos; para adentrarmos no contexto de convivência e cuidados diários com a SCVZ; e para notarmos como a sua presença não é necessariamente suave. Os três medicamentos demonstram como essas mulheres têm se dedicado a entender sua origem, funcionamento, efeitos e consequências, oscilando entre adesão e reticência. São medicamentos que não circulam de modo unânime e despertam uma ambiguidade desconcertante.

O desenho metodológico dessa pesquisa primou por conhecer cerca de uma vintena de mães de micro, como se autointitulavam, que vivem na Grande Região Metropolitana do Recife (RMR), e visitar e manter contato continuado ao longo de quatro anos (2016-2019). A primeira autora esteve em todas as seis temporadas de pesquisa, sempre acompanhada de estudantes de graduação ou pós-graduação. A segunda autora compôs a equipe da sexta e última visita ao Recife, em fins de junho de 2019. Esse acompanhamento diacrônico nos permitiu, no caso dos medicamentos, perceber a flutuação de seus sentidos, faceta que talvez não veríamos se tivéssemos optado por realizar entrevistas pontuais em um único momento da epidemia, como no primeiro surto virótico (2015-2016). Lá atrás, a adesão aos medicamentos foi muito mais naturalizada e esperançosa, mas ao se tornarem recorrentes nas receitas médicas oferecidas aos seus filhos e filhas, esses objetos foram passando ao escrutínio crítico cada vez mais intenso por parte das mães e cuidadoras. Ainda assim, em nenhuma de nossas seis visitas à capital pernambucana os medicamentos deixaram de ser um assunto central de nossas conversas com essas famílias. Dificuldades para serem prescritos, acessados, consumidos, substituídos, desmamados - os medicamentos são um aspecto incontornável no cuidado dessas crianças.

\section{Berotec e os perigosos broncodilatadores}

Alípio nasceu em 2015, à mesma época em que as quase 500 crianças nasceram apresentando severas complicações neurológicas em Pernambuco (Brasil, 2019: 5). Sua família vivia num dos 15 municípios que compõem a RMR e, desde o início, tem recorrido ao aparato biomédico concentrado na capital. Maria Fernanda, sua mãe e principal cuidadora, fazia viagens diárias até consultórios, clínicas de exames e reabilitação, farmácias de alto custo, Ministério Público e também organizações não governamentais que surgiram para dar apoio a essas famílias. Eram muitos quilômetros todos os dias dentro dos ônibus, caronas em carros de parentes ou vizinhos, táxis ou aplicativos de transporte e, mais recentemente, ambulâncias que a prefeitura foi incitada judicialmente a oferecer às famílias de micro de seu município. 
Quando Alípio apresentava algum sintoma novo ou atípico, Maria Fernanda tentava contornar com os primeiros cuidados domésticos. Atenta, observava todos os sinais que o corpo do filho lhe dava. O primeiro cuidado em casa muitas vezes era suficiente para evitar que a criança fosse submetida aos estresses do deslocamento ao hospital, ao barulho do trânsito, às filas e salas de espera. Por isso, primeiro a mãe ajustava a dose do antiespasmódico, mergulhava-o no ofurô improvisado num balde, refrescava-o com o ventilador. Eventualmente, acionava o posto de saúde ou a UPA de sua região, mas nem sempre encontrava profissionais de saúde ou medicamentos a contento. Em uma forte crise de "cansaço" e com dificuldade respiratória, Alípio foi trazido às pressas para um hospital de referência de saúde infantil no centro recifense. Era comum que se procurasse o hospital onde a criança havia nascido, contando que ali estaria o prontuário e toda a sua história clínica, informações que talvez ajudassem os profissionais da saúde a oferecerem cuidados com mais qualidade, de modo mais personalizado.

Diante de uma dessas crises, Maria Fernanda deu entrada no hospital, Alípio foi levado à sala de emergência e atendido pela equipe médica. Foi examinado primeiro e depois medicado com algumas sessões de nebulização. No aparelho, foi colocada uma certa dose de Berotec ${ }^{4}$, um poderoso e conhecido broncodilatador. Maria Fernanda segurava o filho todo esse tempo, próxima e atenta à evolução de seus sintomas. Essa crise foi contornada, mas a médica pediu que a criança ficasse internada para um acompanhamento mais longo. Alípio passou alguns dias no hospital, sempre em sessões diárias de nebulização com o medicamento. Ao final, para a tristeza profunda dessa mulher e sua família, Alípio não resistiu e faleceu.

Maria Fernanda revoltou-se imediatamente e também por muito tempo depois. Interpelou a equipe da enfermaria e, especialmente, a médica que atendeu o filho. Bateu boca, chorou, lamentou-se profundamente pela perda irreparável. A médica tentou responsabilizar a mãe, alegando que a taquicardia sentida por Alípio tivesse sido produzida por algum tipo de negligência antes de chegar ao hospital. Ela insistia que a mãe tivesse reforçado a dose de algum dos medicamentos dados à criança em casa. Seu discurso parecia associar o hospital à segurança, vigilância e controle, enquanto a casa estaria fadada à insegurança e risco (Castro \& Moreira, 2018). “Eu não matei meu filho!”, gritou Maria Fernanda várias vezes pelos corredores do hospital. "Eu dava os remédios certinhos e nunca daria nada a mais pra ele!", complementava.

Ao conversar conosco, ela repetia que o filho tinha dado entrada no hospital com um sintoma geral, o "cansaço", encontrado comumente em qualquer criança. Ela só desejava que ele recebesse uma nebulização com soro fisiológico, técnica que não dispunha em casa, mas a médica prescreveu o Berotec, "apenas cinco gotas do remédio", ela explicou. E concluiu, "foi o remédio pra cansaço que matou meu filho". Ela não se contentou com as informações no dia da morte. "Depois que ele tava no caixão, lá no cemitério, eu fui lá na médica exigir que ela me falasse o remédio que ela botou no meu filho e assinasse num papel”. Maria Fernanda queria um registro por escrito, já que as receitas médicas só são entregues nas consultas e, no caso das internações, são apenas registradas no prontuário. Não

4 Berotec é o nome comercial, dado pela farmacêutica Boehringer Ingelheim, para o bromidrato de fenoterol "indicado para o tratamento sintomático da crise aguda de asma e outras enfermidades com constrição reversível das vias aéreas, por exemplo, bronquite obstrutiva crônica" (Anvisa, 2020a: 1). 
sabemos dos acontecimentos seguintes da história, se Maria Fernanda moveu algum processo judicial contra o hospital ou a médica. Até esse ponto, a declaração explícita por parte da médica de que aquele fora o medicamento utilizado seria suficiente à mãe, que teria o nome do medicamento e o nome da profissional impressos em um papel. Maria Fernanda parecia utilizar o mesmo recurso acionado pela médica que lhe acusara de ter usado algum medicamento em casa. A mãe devolvia na mesma moeda, associando o Berotec à médica, à assinatura, ao hospital. Para ambas, o veneno principal tinha nome, a vilã que o utilizara também. Havia consenso sobre o potencial uso intoxicante dos medicamentos e também sobre a ética do cuidado (Fonseca, 2019; Bellacasa, 2010). Ao se acusarem mutuamente, essas duas mulheres tentavam manter intactas a maternidade e a profissão médica, duas formas diferentes de oferecer cuidados a uma criança doente.

A história de Alípio nos foi contada por várias mães, inclusive por Maria Fernanda. A intenção parecia ser mobilizar uma reflexão mais ampla sobre os locais, os atores, as decisões envolvidas no atendimento de uma criança com SCVZ. O Berotec mais e mais passava a figurar, no imaginário das mães de micro, como um motivo de alerta, como um ponto de inflexão ritual que impelia a uma maternidade mais crítica. A morte dessa criança, compreendida pelas mães a partir do uso iatrogênico do Berotec, foi um momento dramático e traumático para toda a comunidade de micro, abalando o rito costumeiro de relacionamento e delegação de cuidados com os especialistas institucionalizados. Embora precisassem contar constantemente com o aparato biomédico, uma conscientização se espalhava e hospitais, profissionais e medicamentos não eram mais aceitos simplesmente. Cada passo no cuidado com a criança precisaria ser explicado e negociado com essas cuidadoras, a confiança tinha sido abalada. Almejavam uma maternidade mais ativa, com cada vez mais expertise técnica e consciência cidadã. Tudo ia adentrando a seara do "direito à saúde" (Vítor, 2019; Flores, 2016).

Várias mães nos contaram que o Berotec já tinha sido oferecido aos filhos, em algum momento, durante alguma crise. Diante desse fármaco, as crianças haviam apresentado "alergia”, outras tiveram o “coração acelerado", muitas mães já não aceitavam que o medicamento fosse prescrito. Haviam optado por outros itens, exigiam que espaçadores fossem utilizados, preferiam nebulizações somente com soro, e tentavam evitar os hospitais sempre que possível. O caso de Alípio lhes devolvia às noções clássicas do hospital como "morredouros de gente" (Foucault, 1979). A "taquicardia" nos revela um pressuposto importante sobre as crianças com a SCVZ. O Berotec apresentava-se como um medicamento muito forte, sendo fatal com apenas algumas gotas no caso de Alípio. Havia um entendimento de que esses corpos infantis eram mais frágeis e vulneráveis e, por isso, o uso do fármaco deveria ser ponderado. Os medicamentos deveriam reverter os efeitos da síndrome e não debilitar ainda mais esse corpo.

A SCVZ se estabeleceu como um quadro complexo com muitos sintomas e deficiências atingindo diferentes sistemas corporais. Embora os sintomas da SCVZ pudessem ser conhecidos isoladamente em outras doenças e síndromes, a reunião deles foi uma novidade encontrada e lentamente atendida pelos diversos especialistas que se envolveram com a epidemia. Pouco a pouco, os sintomas foram sendo separados e solucionados, com um ir e vir diagnóstico e também prognóstico. Nesse processo, uma intensa experimentação tomou parte de consultórios e também das casas das famílias de micro. Embora alguns protocolos farmacológicos tenham se estabelecido de modo mais geral, cada criança 
exigiu que seus médicos e médicas adaptassem e desenhassem de modo mais personalizado o arranjo de medicamentos.

Os medicamentos administrados nos espaços hospitalares, como o Berotec por exemplo, eram tidos como especialmente ambíguos. O espaço, o profissional, a urgência, a intensidade farmacológica - tudo contribuía para dotar esse medicamento de uma força especial e, claro, de um perigo especial. Em muitos momentos, essas famílias precisaram recorrer a esse aparato especializado da biomedicina, mas isso não significava que lhes dotassem de uma confiança automática. Acionavam esse arsenal tecnológico de modo cada vez mais crítico e precavido - e aqui, retomamos a origem etimológica do termo grego pharmakon, capaz de sarar e envenenar a um só tempo. O Berotec e seus similares portavam uma vida dupla numa única pílula. ${ }^{5}$

E o medicamento penderia mais para um lado do que para o outro a depender de um conjunto de aspectos que essas mães notavam ao permanecer - por dias, às vezes - dentro dos hospitais. Não era apenas o efeito prometido na bula daquele medicamento que determinava sua qualidade. Eram muitos aspectos arrolados e combinados por essa atenta acompanhante da criança. Desde a recepção, onde notavam que o atendimento era proporcional à qualidade de seus "planinhos de saúde" (no caso dos hospitais privados); passando pela enfermaria, onde percebiam como o pequeno corpo da criança era manuseado para a instalação de um acesso ou da limpeza ao redor do leito que a criança ocuparia; chegando à equipe médica, que perguntaria somente sobre o sintoma em questão ou sobre as condições de saúde em geral daquela menina ou menino e depois prescreveria um medicamento que fosse suficientemente eficaz e produzisse minimamente efeitos colaterais.

Um medicamento que tivesse se apresentado nocivo àquela criança, portanto, poderia ser explicado pelo médico que não lera corretamente o prontuário, ou pelo padioleiro que empurrara agressivamente a maca, ou a recepcionista que encaminhara o caso para a ala pediátrica em vez da neurológica e um pouco de tudo isso junto. Queremos dizer que, embora houvesse uma grande expectativa de que os medicamentos resolvessem aquele agravamento de saúde da criança, eles não eram tomados de modo isolado, mas sempre dentro do contexto onde, por quem e como tivessem sido oferecidos. Seu funcionamento acontecia dentro de um quadro mais complexo de cuidados com a SCVZ, dentro do contexto precarizado da rede de serviços e instituições de saúde no Recife.

No caso de Alípio, muitas coisas saíram diferentes do que Maria Fernanda esperava. Teve que ser tratado no hospital em vez de ficar sob os seus cuidados em casa. Recebeu um medicamento, quando queria apenas um procedimento (nebulização). Uma dose excessiva foi prescrita. A responsabilização foi disputada e as desigualdades em termos de escolarização, raça e classe social parecem ter se anunciado em formulações antagônicas como, por exemplo, amadorismo materno versus expertise médica;

5 Com a chegada de suas crianças com a SCVZ, com um nível intenso e continuado de dependência e cuidados, ampliaram e aprofundaram ainda mais seu conhecimento sobre medicamentos infantis, que traziam de seus filhos e sobrinhos anteriores. Tiveram que depender ainda mais dos médicos e farmacêuticos, mas também realizar seus próprios testes e trocas horizontais de informações. Os casos de intoxicação, efeitos colaterais, overdoses, erros médicos etc. se multiplicaram e foram rapidamente circulados entre as mães, entre as associações de cuidadoras da SCVZ e doenças raras. Novas situações de "veneno" surgiram face às situações de "cura" realizadas pelos medicamentos. Por fim, a SCVZ lhes exigiu um cuidado mais intensificado, um aprendizado mais rápido, táticas de testagem doméstica, checagem de informações, interpelações dos médicos. Tudo isso foi lhes fazendo mais críticas, mais atentas. E, portanto, "pharmakon" pode servir de inspiração para esse quadro. 
o improviso doméstico versus o profissionalismo hospitalar. Maria Fernanda, por outro lado, percebia que o contexto clínico e científico, ainda muito instável em relação à SCVZ, abria um enorme flanco de incerteza e talvez até a possibilidade de erros médicos. Não parecia má-fé de sua parte, tentando a todo custo encontrar a explicação sobre a morte do filho, mas para nós comunicava a coragem de desestabilizar saberes historicamente consolidados, como a Biomedicina, e apontar que os protocolos de cuidados com as crianças de micro ainda estavam em construção, precisando de uma participação mais compromissada e ativa de todas as partes envolvidas.

\section{Depakene e os controversos anticonvulsionantes}

O caso dos anticonvulsionantes é especialmente interessante para vislumbramos as ambiguidades que medicamentos podem assumir na infância com SCVZ. Especialmente no início do diagnóstico, a irritabilidade, o choro por horas e horas, dezenas de convulsões por dia, o estado de vigília e exaustão das crianças foi relatado por todas as mulheres que conhecemos. Profissionais de saúde se dedicaram por muitos meses para encontrar o tipo, a dose, a administração mais adequada para acalmar cada uma dessas crianças. Medicadas, elas conseguiram dormir por mais tempo, desenvolveram apetite, crescer e ganhar peso. Sem crises, elas não desaprendiam o que vinham sendo ensinadas pelas profissionais de reabilitação e iam ganhando ferramentas para interagir mais ativamente com sua família e o mundo. A casa poderia retomar alguma rotina, poupando e desonerando um pouco as mulheres, sobretudo. Em geral, para muitas dessas crianças, esses medicamentos precisaram continuar em uso. Se fossem retirados, produziriam as nocivas reações ao desmame e retomariam os sintomas. Completavam quatro anos de idade em 2019 e a maior parte se mantinha medicada diariamente.

Em nossa primeira visita ao Recife, ainda em 2016, conhecemos Roberto. Ele não tinha completado um ano de vida e estava no colo de um de seus irmãos. Era um pouco depois do meio-dia, fervia de calor. Dona Rosa, sua mãe, pediu que o mais velho levasse o caçula para tomar um banho e se refrescar no tanque ali do lado de fora. Surpreendemo-nos que os cuidados de um bebê com a SCVZ fossem delegados a outra criança. Roberto voltou com os pequenos cachinhos pingando água e em pura alegria. O irmão o enxugava e a criança fazia graça por baixo da toalha. Depois, Dona Rosa lhe deu um biscoito e ele ficou a lamber o recheio demoradamente. Olhava para a mãe, para o irmão, para nós e sorria, com chocolate escorrendo pelos cantos da boca. Roberto interagia com todos ali naquela pequena casa de fundo, num subúrbio distante da capital. Estava desperto e presente, circulando por toda a sala aqueles seus grandes e pestanudos olhos cor de caramelo.

Dona Rosa nos explicou que, assim que nasceu, prescreveram medicamentos para Roberto não chorar tanto, não se irritar tanto e para dormir melhor. Ela deu um pouco, observou outro tanto. Retomou sua própria experiência, anos antes, com os "tarja preta", quando foi diagnosticada com depressão. Ciosa, começou a suspeitar dos medicamentos receitados ao filho. Diminuiu a dosagem, fez o desmame vagarosamente. Víamos uma criança "trelosa”, como se dizia por ali, tentando descer sozinho do colo da mãe, arrastando-se pelo chão até encontrar a barra da calça de uma das pesquisadoras, puxando-se para cima, rindo o tempo todo. 
Embora reconhecesse que muitas crianças passaram a ter menos convulsões e a tranquilidade voltara a reinar nessas casas, Dona Rosa suspeitava que, ao consumir tantos medicamentos, elas ficassem com excessivo sono, fome e letargia. Ela argumentou ainda que, embora essas crianças, uma vez medicadas, não tivessem mais crises que comprometessem seus aprendizados fisioterápicos ou fonoaudiólogos, muitas vezes, não conseguiam nem permanecer acordadas no momento dessas sessões de terapia. Com isso, perdiam a consulta e corriam o risco de serem desligadas do serviço. Ou sequer retinham os ensinamentos, já que chegavam dormindo e as terapeutas passavam parte da sessão tentando acordá-las ou caíam no sono no meio dos exercícios e a sessão terminava antecipadamente. Dona Rosa disse, em relação a outra criança de micro que tomava vários desses medicamentos, "Ele fica olhando assim o tempo. Ele não se mexe, fica só olhando pro nada”.

Se, antes do medicamento, a criança não conseguia avançar em seus aprendizados porque convulsionava demais, agora, com o medicamento "controlado" (como chamavam os anticonvulsionantes, os "tarjas pretas"), tampouco havia aprendizado porque vivia no sono ou no "nada". Dormir o tempo todo ou estar acordado apenas de corpo presente eram condições que dificultavam o trabalho terapêutico, a criança poderia não receber ou receber apenas de modo passivo e sem registro consciente o que se passava ao seu redor. "Olhar para o tempo" era grave porque, no mundo da micro, cada fração do tempo contava ao precocemente oferecer tudo que fosse possível a essas crianças, numa esperança de que apressar a estimulação compensaria as limitações apresentadas pelo quadro da SCVZ (Fleischer, 2017; Fleischer \& Alves, 2019). Por outro lado, a criança dormir algumas horas do dia, especialmente quando a intensa circulação pelas clínicas e farmácias da cidade estava em curso, era bem aproveitado por essas mães que optavam pelo medicamento. Muitas, por exemplo, só tiveram a oportunidade de desenvolver sua liderança política em prol da SCVZ, participando de inúmeras reuniões na prefeitura, nas empresas de transporte, no Ministério Público ou na Secretaria de Educação, porque transportavam e conviviam com o filho sonecando.

Mas conviver com um medicamento por muito tempo ou em doses muito altas pode gerar dependência, como Dona Rosa tinha notado quando ela própria tomou remédios anos antes. À certa altura, um medicamento parava de produzir o efeito desejado na criança e outro fármaco semelhante era adotado. Nessa substituição, a criança poderia ter uma recaída dos sintomas que, com o uso do primeiro medicamento, não mais existiam. Ruim com o medicamento, pior sem ele, concluíam. Provavam, nessas ocasiões, como o medicamento era forte, mas também notavam como sua força se sobrepunha à da criança, impedindo que ela pudesse existir sem sua presença, impedindo que ela pudesse avançar e encontrar formas de se autonomizar. Para além dos sintomas da SCVZ, Dona Rosa apontava que, com os medicamentos, novos e inesperados sintomas surgiam. A natureza ambígua do medicamento aos poucos se apresentava.

Dona Rosa nos explicou ser fácil identificar as crianças que seguiam essas prescrições: eram gordinhas. Muitas apresentaram dificuldade de alimentação e crescimento e, como solução, passaram a 
receber a comida via sonda naso ou endogástrica ${ }^{6}$. Os leites eram próprios para o uso via sondas e bastante caros. Então, também no caso da SCVZ, gordura era um valor estético, nutricional e financeiro. Mas Dona Rosa tensionava essa dimensão corporal porque, ao caminhar para a obesidade, a criança teria mais dificuldade para movimentar o corpo e fazer os exercícios de reabilitação ou mesmo para ser carregada no colo pela mãe até essas clínicas. No final das contas, refletia Dona Rosa, quanto mais gorducha, menos exposição essa criança teria às terapias e mais alto seria o nível de deficiência. Pronunciava-se uma associação entre um medicamento, um tipo corporal, um grau de SCVZ e, finalmente, um quadro de estigma. O medicamento, no entendimento dessa mãe, assumia um caráter delator sobre o nível da síndrome e o tipo de maternidade em curso.

Vozes críticas, como a de Dona Rosa, achavam que os medicamentos estavam servindo mais às mães do que às crianças de micro, numa medida terapêutica estratégica, acomodada e egoísta. Nessa resistência aos anticonvulsionantes, como um dos mais usados, o Depakene ${ }^{7}$, parecia pairar uma suspeita de superdosagem ou de iatrogenia profissional e materna, numa tentativa de sedar essas crianças em vez de amenizar de outras formas sua irritabilidade e epilepsia. Uma outra mãe, inclusive, contou-nos ter sido acusada pela médica de ter dado "remédio controlado" ao filho que tivera uma convulsão inesperada. Quer dizer, mesmo entre os prescritores, estava evidente o grande potencial desses medicamentos para tratar, mas também para prejudicar. É interessante que um medicamento pudesse resolver e, ao mesmo tempo, acentuar um mesmo sintoma, parecendo caminhar sobre uma linha muito tênue. E, pelo que entendemos, era sobre essa linha que as mães de micro precisavam aprender a transitar para cuidar de seus filhos e filhas com SCVZ. Dona Rosa acusava as mães de micro de confiarem cegamente nos profissionais de saúde e nos medicamentos que prescreviam, incitando-as a se posicionarem de modo a priorizarem a saúde e o desenvolvimento dos seus filhos. Ela não estava disposta a ponderar sobre os benefícios do Depakene.

Ao mesmo tempo, mães como ela pareciam estar comunicando um autocongratulamento pelo fato de oferecerem um cuidado tão exitoso a ponto de tornar os medicamentos desnecessários. Poderiam também estar revelando a sorte de seu filho ou filha ter uma "micro leve", como diziam. Ela nos contou, "Roberto não teve convulsão, só espasmos de vez em quando, treme um pouquinho aqui e ali. Mas só isso". Interessante que, durante uma de nossas visitas à casa, o filho primogênito, de 15 anos à época, explicou que sabia como oferecer os primeiros socorros caso o irmãozinho tivesse uma convulsão. Refletimos sobre ele ter adquirido essa habilidade, mesmo a mãe repetindo tantas vezes que a criança não tinha crises. Não tomar medicamentos positivava a maternidade, desafogava o orçamento doméstico, revelava um menor grau de deficiência, reduzia a prioridade dos encontros clínicos que viabilizassem as receitas etc. Uma outra mãe que participava de nossa pesquisa aproximou mais sua

6 A sonda nasal é um tubinho de PVC que entra desde as narinas e vai até o estômago. Já a sonda endogástrica, ou gastrostomia, o tubinho entra diretamente no estômago, via a pele da barriga. A primeira só deve ser usada por até seis meses, tendo intenção transitória. A segunda é mais duradoura.

7 Depakene é o nome comercial, dado pela farmacêutica Abbott, para o ácido valproico, "indicado isoladamente ou em combinação a outros medicamentos, no tratamento de pacientes adultos e crianças acima de 10 anos com crises parciais complexas, que ocorrem tanto de forma isolada ou em associação com outros tipos de crises. Também é indicado isoladamente ou em combinação a outros medicamentos no tratamento de quadros de ausência simples e complexa em pacientes adultos e crianças acima de 10 anos, e como terapia adjuvante em adultos e crianças acima de 10 anos com crises de múltiplos tipos, que inclui crises de ausência” (Anvisa, 2020b: 1). 
filha da "normalidade" porque ela não tomava remédios, numa clara associação retrospectiva entre o medicamento consumido, o sintoma identificado e, por fim, o nível de deficiência implicado. E ainda outra nos contou que, em comparação com crianças que vinham tomando muitos medicamentos, o dela - que não tomava - já estava balbuciando as primeiras palavras, dando os primeiros passos, querendo "trelar" o tempo todo.

Nos últimos meses de gestação, Dona Rosa ouviu que seu bebê apresentava algum "problema”. Quando nasceu, isso foi confirmado e anunciaram que Roberto tinha "microcefalia" e iria para sempre "vegetar". Claro que ela ficou alarmada com tudo isso, mas passou a observar o filho atentamente. "Com três dias, ele levantou a caixa do peito assim para cima do berço. Nenhuma criança faz isso com essa idade. Isso foi para calar a boca dos profissionais de saúde”, explicou. A desenvoltura de Roberto desafiava o diagnóstico fatalista e nos ficava cada vez mais claro que a opinião especializada não era tomada por essa mãe como a única versão sobre os fatos. Recorria a muitas outras fontes, comparava seu filho com outras crianças com a SCVZ, circulava pela cidade e colhia diferentes informações. Essa polifonia ajudava a relativizar o que vinha oficialmente das autoridades biomédicas. Dona Rosa contou de uma outra mãe de micro, muito próxima dela, que "aceitava fácil demais o que os médicos diziam". Ao filho dessa colega, foi prescrita a cadeira de rodas. Dona Rosa foi contundente, "Eu falei para ela pensar melhor. Por que cadeira? Por que ele não poderá andar? Tem sempre uma luz no final do túnel, eu falei para ela. Ela aceita muito, tem que pensar, tem que ver outro jeito”. Depois, voltou-se novamente à descrição da trajetória de Robertinho: “A gente está surpreendendo a medicina. Eu já falei isso para geneticista dele. Ela fica sem saber como ele está conseguindo fazer tudo isso. Falaram que ele não ia engatinhar. Ele engatinhou. Ele segurou nas coisas, ele sobe e desce dos móveis. Ele até foge para rua! Tive que tirar o berço dele do quarto porque ele tava saindo do berço, ele pode cair e se machucar no chão. Falaram que ele não ia caminhar, caminhou. Eu não aceitei que ele não ia andar. Falaram que ele não ia falar e ele está começando a falar. Deus faz a obra. Ele faz a obra dele”. Dona Rosa se fiava em outro conjunto de verdades, como nos disse assim que nos conhecemos, ainda em 2016, "Primeiro de tudo, eu me apego a Deus. Antes de tudo. É a coisa mais importante”. Como nos mostrou Cheryl Mattingly, ao analisar a história de um casal tomando decisões para salvar a sua filha recém-nascida e internada como uma severa espinha bífida, no "laboratório moral" acionado para realizar o cuidado, por vezes, há "tradições morais rivais" (2014: 154). Parecia ser o caso dessa família, com Dona Rosa intensificando a disputa entre a medicina dos homens e os milagres de Deus. Roberto desafiava outras lógicas e moralidades e parecia ser a prova da vitória divina.

Mas a não adesão poderia também esconder, por exemplo, dificuldades financeiras da família para conseguir comprar os medicamentos que haviam sido prescritos e que não eram encontrados gratuitamente nas farmácias públicas. Ela e o marido pelejavam para dar conta de todos os gastos da família. Lembramos que, por conta do alto custo, Dona Rosa tinha desistido, por exemplo, de comprar os leites vitaminados, sempre receitados pelas médicas que julgavam Roberto muito "magrinho". Talvez não medicar poderia ser uma tentativa de evitar novos estigmas associados a esses medicamentos. Mães como Dona Rosa talvez preferissem não ser vistas nas filas das farmácias de medicamentos controlados, não ter o filho/filha chamado de "epilético", "doidinho" ou "monstro", algumas das alcu- 
nhas ofensivas que nossas interlocutoras ouviram ser dirigidas aos seus filhos e filhas. E, quando o não tomar não era uma escolha, mas uma realidade vivida compulsoriamente pela criança, poderia revelar sofrimento e violências.

De qualquer modo, no caso do Depakene e similares, uma mãe poderia ser criticada por ter demorado muito tempo para resolver as crises do filho ou filha, fazendo com que sofresse dezenas de convulsões por dia e corresse risco de vida; ou, na outra ponta, por ter aceitado uma posologia exagerada, deixando a criança dopada grande parte do tempo. Dar ou não dar o medicamento produzia efeitos intensos, que respingavam com facilidade na forma como aquela maternidade seria avaliada na família, no consultório, nos espaços de convívio com as outras mães de micro. Dona Rosa precisava, com muitos argumentos de autodefesa e "alter crítica", explicar por que tinha descontinuado os anticonvulsionantes de Roberto. Suspender uma receita médica era também uma forma de automedicação e de desafio à autoridade sanitária e, portanto, precisava ser justificada. Roberto teve a sorte de enfrentar menos crises que seus contemporâneos e de nascer de uma mãe que queria evitar o Depakene e todos seus efeitos colaterais. Mas Dona Rosa não concordava conosco sobre essa sorte aleatória - as razões da saúde e desenvolvimento do filho passavam, sobretudo, pelos desígnios divinos. A saúde e alegria de Roberto eram um presente que aquela família tinha merecido receber.

\section{Zodel e os estigmatizados antidepressivos}

Ludmila foi uma das primeiras mães de micro que conhecemos. Ela tinha quatro outros filhos quando nasceu sua caçula, Anita. Gestação tranquila, mas parto complicado. Ela já vinha conversando com a médica para que o procedimento fosse cirúrgico para também incluir uma laqueadura. Uma vez no hospital, mesmo em meio a contrações, Ludmila teve que empreender uma larga negociação para que seu planejamento reprodutivo fosse respeitado. Ainda assim, explicou ter recebido menos anestesia do que deveria, beirando a tortura. Depois, ficou duas semanas internada, sem poder voltar para casa e cuidar dos outros filhos, porque Anita logo foi revirada do avesso com exames, fotografias, medições e medicamentos. Novamente, teve que brigar para que a filha não se transformasse em cobaia para os estudantes e residentes da Medicina. Voltaram para casa cansadas e assustadas diante do diagnóstico da SCVZ.

O marido de Ludmila, desde o início, resistiu em aceitar a notícia da deficiência. Por conta disso, duvidava que a esposa estivesse circulando com a menina para garantir vagas em consultas, exames e terapias. Acusava-a de adultério, questionava o alto gasto com passagens de ônibus e medicamentos, devassava suas mensagens de celular para entender por que Ludmila precisava tanto conversar com outras mães de micro e profissionais de saúde. Para conseguir os tratamentos para a filha e a doação de mantimentos e itens de puericultura, Ludmila tinha que frequentar ONGs, faculdades e instituições de saúde ao redor da cidade. E, portanto, precisou fechar sua mercearia, ver sua renda reduzir-se drasticamente e contar apenas com o Benefício de Prestação Continuada (BPC). A falta de cumplicidade com o marido fazia com que fosse a única responsável pela saúde da criança e pela manutenção da casa. A avó materna, à época do nascimento de Anita, condicionou qualquer ajuda a algum pagamento. $\mathrm{O}$ 
avô materno tinha falecido fazia alguns anos de cirrose hepática. O tio materno tinha envolvimento com o tráfico de drogas. Ludmila havia mudado de casa umas três vezes, tentando equilibrar a queda vertiginosa de renda e, por isso, não tinha ainda uma rede de vizinhas com quem poderia contar. Ela acumulava muitos turnos de trabalho a responsabilidade exclusiva pela prole.

Numa tarde, ao abordar um ônibus de volta para casa, o motorista questionou o uso de passe livre por Ludmila e Anita. Ela retrucou, virou um bate-boca, terminou na delegacia. Ludmila não admitia que o direito que sua filha tinha de circular gratuitamente pela cidade fosse questionado, não suportava ver o preconceito contra sua deficiência. Teve forças ainda para abrir um processo de danos morais contra essa empresa de transporte e seu motorista. Mas esse episódio foi-lhe a gota d'água. Criou trauma de ônibus, não conseguiu mais sair de casa, perdeu todas as vagas nas terapias e doações, viu a menina definhar sem acompanhamento, medicamentos e leites especiais. Até o BPC estava sob risco já que Ludmila não encontrava forças para renovar a documentação na assistência social da prefeitura.

Foi nesse contexto crítico, de solidão, sobrecarga, violência e desespero, que Ludmila conseguiu uma consulta com uma psiquiatra. Nós nos falamos pelo Whats $A p p$ justamente naquela semana e ela resumiu sua satisfação: “Eu consegui um CID para chamar de meu!”. Para nós, a frase soou forte e medicalizante, mas fazia sentido no processo de restabelecimento que Ludmila precisava enfrentar para continuar cuidando de sua família. A consulta gerou um diagnóstico (a Classificação Internacional de Doenças e Problemas Relacionados à Saúde, também conhecida como CID), uma receita médica e o acesso ao $\mathrm{Zodel}^{8}$, um potente psicotrópico antidepressivo. O número do CID e o processo judicial contra a empresa de ônibus foram documentos importantes para justificar a longa ausência nas consultas, nas terapias de reabilitação e nos grupos de mães durante os últimos meses. Foi só começar a tomar as pílulas que Ludmila sentiu suas forças voltarem, a vontade de arrumar a casa, mandar as crianças para a escola, capinar o quintal e circular novamente com Anita pelos seus atendimentos. Contou-nos também que vinha compartilhando uma bandinha da pílula com o marido, que retomava a disposição para deixar de beber e procurar trabalho. Longe do alcoolismo, inclusive, ele se tornava muito mais cooperativo para cuidar da filha. Ludmila portava suas cartelas laranjadas com muito orgulho e somente o preço, R \$130, lhe preocupava sobre o futuro. Agora, dependia daquele medicamento para continuar sendo uma boa mãe, uma boa mãe de micro.

Muitas mulheres contaram histórias semelhantes à de Ludmila, de terem encontrado no psicotrópico a forma de manter a tranquilidade e a força para atender as demandas do/da caçula com a SCVZ e continuar cuidando da família (Martin, Caccozi, Macedo \& Andreoli, 2012). Nem todas contavam sobre isso de modo tão aberto como Ludmila, contudo. A regra, na verdade, era uma continuada tentativa de demonstrar fortaleza e retidão, de reforçar como nunca haviam precisado de antidepressivos. E, nesse sentido, a longa história que Ludmila contava para nossa equipe, mas também para outras pesquisadoras, profissionais de saúde, assistentes sociais, talvez fosse uma complexa justificativa para o consumo do Zodel. Ela poderia estar tentando legitimar esse medicamento, reforçando os as-

8 Zodel é o nome comercial, dado pela farmacêutica Medley/Sanofi, para o succinato de desvenlafaxina monoidratado, "indicado para tratamento do transtorno depressivo maior (TDM, estado de profunda e persistente infelicidade ou tristeza acompanhado de uma perda completa do interesse pelas atividades diárias normais)" (Medley, 2021:2). 
pectos externos, aqueles que chegavam alheios à sua vontade. Parecia ser um esforço para despregar o Zodel de sua pessoa, sua identidade, sua maternidade.

Talvez a presença do medicamento psicotrópico fosse desconfortável por conta do risco de estigmatização, como começava a se anunciar para as crianças "dependentes" de Depakene, como Dona Rosa nos mostrou na última seção. Em uma sessão de terapia coletiva que acompanhamos, uma mãe foi muito vocal. Primeiro, ela criticou a troca aleatória da fisioterapeuta de seu filho. A criança passou a rejeitar a nova médica, retraindo-se muitíssimo de participar e pouco avançou, a partir dali, em seu processo terapêutico. Depois, essa mãe reclamou que uma colega de um município do interior tinha tido o filho cortado repentinamente de duas terapias, dificultando que ela justificasse o carro da sua prefeitura para the trazer ao Recife apenas uma vez por semana para a terapia que havia restado. Essa mãe continuou pontuando vários problemas que via na organização dos serviços de reabilitação que aquela clínica se propunha a oferecer.

A certa altura, a psicóloga que acompanhava o relato disse que talvez ela poderia tomar algum medicamento para se acalmar. A mãe fica indignada com a sugestão de que estivesse sendo classificada como "louca" ou "descontrolada", já recebendo a um só tempo diagnóstico e prescrição. Ela se defendeu, estaria apenas pontuando problemas do serviço, papel que caberia a todas as mães de micro e demais pacientes que ali frequentavam. Terminou seu desabafo, lembrando que, tempos atrás, um psiquiatra lhe receitou um psicotrópico e, aí sim, tinha ficado "tarantantan de verdade". Com o exemplo, ela atribuía o poder de "endoidecer" ao medicamento e não à postura crítica como uma mãe ativa de uma criança com SCVZ. "Mas anotem aí, eu não sou doida, não", terminou dizendo. Com esse depoimento final, ela arrancou risos das psicólogas, das demais mães e de nossa equipe de antropólogas que acompanhava essa sessão de terapia coletiva. Mas seu recado tinha sido muito bem dado. Mostrava como diagnósticos, prognósticos e medicamentos, mesmo que informalmente anunciados, já tinham um grande potencial classificatório. Ela não queria, de forma alguma, passar a impressão de que, por alguma instabilidade, estaria inapta a oferecer uma boa maternidade aos dois filhos, o menor com a SCVZ.

Ademais, é interessante notar o efeito retrospectivo do medicamento nos dois casos. A criança que tomasse um Depakene indicava ter uma microcefalia mais aguda, sofreria mais intensamente dos efeitos compreendidos na SCVZ. A mulher que tomasse um Zodel indicava ter algum nível de instabilidade mental, psíquica ou emocional. Deficiência e loucura andavam juntas aqui, mas com pesos morais diferentes. Cabe ainda notar que quanto mais deficiência a criança apresentasse, mais instabilidade seria creditada à mulher; na mesma toada, quanto mais Depakene fosse prescrito, mais Zodel seria necessário.

Podemos chegar ao limite, inclusive, de encontrar acusações de loucura prévia na mãe como razão da apresentação do diagnóstico sindrômico no filho que foi por ela gerado. Várias mulheres foram perguntadas, pelas médicas e médicos que tentavam fechar o diagnóstico da criança, se elas haviam tomado "remédio para abortar" ou se estavam tomando "remédio controlado" à época da gravidez. Os medicamentos poderiam servir como pistas sobre a saúde mental dessas mulheres. Não somente durante a gravidez, mas já com a criança nos braços, essas associações estigmatizantes poderiam continuar. 
Algumas interlocutoras lembraram de conhecidas que, ao caírem em depressão, mesmo tentando contar com o apoio dos medicamentos, haviam deixado de lado o cuidado com o filho. Em um caso, inclusive, a criança nunca chegara a falar. A mãe, vista como "doente da cabeça”, era diretamente responsabilizada pelas habilidades pouco desenvolvidas do filho. Infelizmente, esses casos não mencionavam outros atores que poderiam - ou deveriam - ter entrado para assumir o cuidado da criança enquanto ela se recuperava. Assim, quando as mulheres decidem, finalmente tomar algum medicamento, correm o risco de serem acusadas de comprometer uma gravidez, de não zelar por um filho ou filha ou até por criar ou acentuar a deficiência que ele/ela porventura tivesse ou viesse a desenvolver. Estavam navegando por suspeitas morais travestidas como suspeitas biomédicas e farmacológicas.

Os psicotrópicos suscitavam muito debate na comunidade da micro. Ainda assim, parecia ser entendido como muito mais grave uma mãe que necessitasse de um psicotrópico do que uma criança. Quer dizer, a criança nascera com o que se chamava localmente de "problema”, ela não havia contribuído de nenhuma forma para precisar tomar um "remédio controlado". Era mais grave no caso materno porque, em desequilíbrio, essa mulher poderia não contar com as condições de cuidar de seu filho, colocando em risco a um só tempo as duas vidas envolvidas. Essa parecia ser uma das interpretações, associando a mulher sempre à responsabilidade com a sua prole. Não era fortuito que medicamentos como o Zodel fossem pouco comentados entre essas mulheres e, quando apareciam nas narrativas, como no caso de Ludmila, eram hiperpositivados, inclusive, para enfatizar a gravidade dos acontecimentos que ela enfrentava na vida cotidiana.

Tampouco nos passava despercebido que os medicamentos destinados às nossas interlocutoras eram discutidos à luz do seu papel como mães. O quadro de saúde dos filhos e filhas não era uma questão dissociada do quadro de saúde delas próprias. Muitas mães relacionavam sintomas como o aumento das crises convulsivas não só com fatores exógenos, como o desmame de algum medicamento, mas também com fatores emocionais sentidos pelas crianças, como uma ruptura na rotina familiar, ou um momento de estresse ou tristeza vivido pela própria mãe. "Ele sente tudo isso. Se eu estou atacada, cansada, ele sente. E aí vai e ele adoece. Ele sente tudo que a gente sente”, uma mãe nos explicou. Por um lado, essa mãe nos chama atenção para a própria agência da criança e em seu papel enquanto sujeito completo e perceptivo (Valim, 2017). Por outro, também chama atenção como pode haver uma autoresponsabilização rigorosa no que diz respeito à saúde dessa criança, justificada e embasada pelo vínculo materno. A saúde mental dessa mãe não está, para ela, separada do quadro de saúde mais amplo do filho.

As mães pareciam ponderar, de modo prioritário, que esses medicamentos poderiam colocar em risco sua capacidade de oferecer uma boa maternidade e não os efeitos colaterais, dependência, complicações sobre a saúde dessas mulheres. Ao mesmo tempo, os riscos que os medicamentos poderiam oferecer às crianças passavam pelo desempenho dessas mulheres como cuidadoras e mães. Quando o assunto eram os medicamentos, elas eram enredadas duplamente, tanto por zelarem pelo bom uso desses objetos terapêuticos (no caso de Berotec e Depakene, para ficar com os exemplos etnografados aqui), quanto por garantirem a boa maternidade (no caso do Zodel, por exemplo). Ludmila parecia 
nos dizer que o custo de dar conta dessa dupla tarefa era que ela também consumisse medicamentos, mesmo que seus efeitos colaterais a longo prazo não estivessem totalmente claros ainda.

\section{Que efeitos a ambiguidade dos medicamentos produz?}

Salvavam vidas, acalmavam crises, suavizavam os problemas da vida cotidiana. Berotec, Depakene e Zodel são utilizados por muita gente, para diferentes desafios e patologias muito além da SCVZ. Nesse artigo, foram trazidos como exemplos de tantos outros medicamentos utilizados por essas famílias para lidar com os sintomas e as reverberações da síndrome do Zika sobre as crianças e sobre toda a família. Mas, à medida que eram colocados em uso, poderiam também se apresentar como perigosos, controversos e estigmatizantes. Os medicamentos percorriam uma carreira duvidosa. Como podemos ver nesse contexto da SCVZ, não contavam com um conjunto estático ou estável de atribuições, efeitos, opiniões. A realidade corriqueira era de ambiguidade, o que poderia produzir diferentes efeitos sobre essas mães e as demais cuidadoras.

Para começar, imaginamos que a relação mais desejada com a biomedicina seria de confiança plena nos cuidados recebidos. Ter um medicamento prescrito que não gerasse o resultado esperado ou que estimulasse novos e mais sintomas nocivos poderia provocar muita frustração ou até trauma, como vimos no caso do Berotec. Mais do que isso, poderia provocar desencantamento com os profissionais e tecnologias da biomedicina e desesperança de encontrar terapêuticas "mágicas", que revertessem ou, no mínimo, contivessem a SCVZ. Também por isso, Dona Rosa, Maria Fernanda e suas colegas não conseguiam mais acreditar tanto nos profissionais de saúde. Iam adotando uma atitude de cautela e desconfiança. Outras explicações sobre a síndrome, outras soluções e especialistas vinham sendo acionados. Elas se apegavam a outras fontes de verdades também.

Ao mesmo tempo, essas mulheres foram paulatinamente entendendo a complexidade dos diagnósticos de seus filhos e filhas e as muitas tentativas e erros realizados pelos terapeutas indicaram como ainda está instável e em plena construção o estado clínico-científico sobre a síndrome e também a epidemia. Reconhecer esse quadro também permitiu que entendessem que a experimentalidade era um aspecto recorrente nos cuidados com essas crianças nas instituições, então que fosse também em casa. Testar um medicamento, uma dose, um horário, uma marca eram todos exercícios para acertar uma posologia mais personalizada. Os experimentos revelavam a versão mambembe de quem prescrevia, quem administrava, quem consumia.

Nesse sentido, a ambiguidade do medicamento poderia se apresentar também como uma nova faceta inesperadamente positiva. Embora pudesse tender para o bem ou para o mal, era sua plasticidade que se revelava, abrindo toda uma arena de possibilidades para novos encontros exitosos entre o corpo da criança e a química do medicamento. Resultados não imaginados de antemão ou sequer previstos na bula poderiam melhorar sintomas. Um processo de re-esperança se iniciava, portanto.

Essa atmosfera de experimentação também criava um novo espaço de participação para essas mulheres. Dada a novidade da síndrome, os profissionais de saúde apostavam que os efeitos dos medicamentos prescritos poderiam também ser documentados no cotidiano doméstico. Eram as mães a 
administrar os pós, sprays e líquidos aos filhos e filhas e, mais importante, a notar os efeitos gerados. Observar, registrar e depois comunicar tudo isso no retorno ao consultório era uma etapa bastante importante no acompanhamento terapêutico daquela criança, no conhecimento daquele medicamento, no cercamento científico da SCVZ. Vimos alguns médicos e médicas anotando minuciosamente no prontuário o que era relatado pela mãe durante as consultas. O itinerário farmacológico daquela criança era substancialmente informado pela sua principal cuidadora. O status dessas mulheres passava, portanto, a um tipo de pesquisadora, de clínica, até de farmacêutica (Rios, 2019; Mundaréu, 2020). E poderiam, como contou Dona Rosa, surpreender a medicina e os médicos e médicas. É da surpresa que avança a ciência, afinal (Peirano, 2008).

A desconfiança que essas mulheres iam acumulando em relação aos profissionais de saúde, que receitavam medicamentos perigosos, e aos cientistas, que nunca lhes devolviam os resultados de tantos testes e exames que haviam feito nas crianças, vinha lhes motivando a negarem a participação em futuros experimentos. Entendiam a instabilidade da síndrome e da tecnologia, mas não queriam mais ver os filhos furados, devassados, atropelados pela ciência (Simas, 2020). Talvez elas também, num futuro próximo, decidissem fazer as próprias pesquisas sobre a SCVZ e os medicamentos mais adequados para seus filhos e filhas, como já foi descrito em outros movimentos de mães e pais que conviviam com as patologias raras de suas proles (Novas, 2006; Rabeharisoa, 2006; Scott, Quadros, Silva, Lira, Matos, Souza \& Saraiva, 2017). Seria uma forma de realmente assumir a ambiguidade dos medicamentos como uma oportunidade para mais estudo e entendimento.

Acreditamos que as histórias que contamos aqui, e que poderiam ter sido sobre muitos outros medicamentos que circulam dentro dessas casas no Recife, informam sobre muitas facetas do contexto da SCVZ. A partir desses pequenos e coloridos objetos, pós e líquidos, conhecemos sobre a complexidade de sintomas, atores envolvidos, espaços terapêuticos, participação das mães. Mas os medicamentos, dada a sua natureza ambígua, são, acima de tudo, dilemáticos. Apresentam situações muito difíceis e que exigem que essas mulheres conheçam, avaliem e decidam. Por vezes, a decisão era escolher qual sintoma era menos negativo, sabendo que não se livrariam totalmente dos sintomas. Outras vezes, a escolha era entre sintoma conhecido e desconhecido, ou entre sintoma e efeito colateral. Mas quanto uma pequena criança aguenta de sintomas, efeitos, medicamentos fortes, bem como também experimentos? Quanto sofrimento vale a pena? Até quando se deveria apostar num medicamento controverso no presente para apostar num futuro com menos crise, dor, mal-estar?

Todas essas histórias, que trazem prós e contras dos medicamentos, vantagens e desvantagens, são fábulas de ponderação e cuidado. Como sugere Mattingly (2014), que por tanto tempo também etnografou a saúde infantil na Califórnia, um laboratório moral precisa ser colocado em prática todo dia. O intenso debate que Berotec, Depakene e Zodel criavam também produz um ambiente de esclarecimento, amadurecimento, tempo de reflexão para se tomar decisões. Elas ouviam relatos das outras mães, circulavam opiniões sobre os diferentes usos dos medicamentos, testavam interpretações sobre todas essas posologias. Esses debates, dentro de uma família, entre as mães de micro, com as pesquisadoras e médicas, eram genuínos exercícios de compreensão sobre uma realidade tão intensa, que se estabelece com uma síndrome desconhecida, um filho ou filha com severas deficiências, um contexto de recursos limitados. 
A nosso ver, esse esforço todo por conhecer, ponderar e decidir sobre os controversos medicamentos empregados para conter a SCVZ estava completamente inserido numa ética do cuidado (Fleischer, 2017; Scott et al., 2017, 2018). Dentro das condições dessas famílias e dos medicamentos que estavam à disposição nas farmácias pernambucanas, essas mulheres tentavam encontrar o que fosse melhor ou, ao menos, menos nocivo às suas crianças. Era um quadro limitado em tantos sentidos, mas elas pareciam aguçar a imaginação para pensar em outras saídas, outras combinações farmacológicas, outros profissionais mais sensíveis aos seus relatos domésticos. Falar de medicamentos - oferecendo-os ou não aos filhos - é falar de cuidado materno. Nossa aposta é que essa maternidade de micro, dados esses desafios e dilemas cotidianos, vai se tornando cada vez mais numa maternidade crítica.

Por um lado, o entusiasmo com o Depakene ou com o Zodel pode parecer uma maior identificação com o modelo biomédico. Como na imagem que abriu esse artigo, seria acreditar no Papai Noel, que ele sempre voltaria e que os presentes trazidos seriam sempre bonitos. Um certo idílio natalino, de renovação de confiança e também de esperança. Por outro lado, o risco do Berotec, as contradições do Depakene e o estigma do Zodel lembram que os presentes podem nem sempre ser como imaginamos ou desejamos. Essas mães iam desenvolvendo um olhar crítico sobre os tratamentos oferecidos aos seus filhos e inevitavelmente desencantando a cena natalina, ou as cenas que de alguma forma esperamos reencontrar nos consultórios, nos hospitais, nas farmácias.

Esse quadro que vimos no consultório em Recife nos provoca a refletir se os medicamentos têm contribuído para criar uma infância hipermedicalizada no cenário da SCVZ e, ao encontrarmos Berotec, Depakene e Zodel embrulhados como presentes ao pé da árvore de Natal, também contribuído para naturalizar esses objetos como dádivas típicas da infância. Ao mesmo tempo, um quadro desses, assinado por uma empresa farmacêutica, só poderia mesmo ser encontrada acima de uma maca, em um consultório, dentro de um hospital. Para nós, os medicamentos, pela quantidade e pela intensidade encontrada nos espaços da SCVZ, não pareciam estar caindo numa banalização, numa incorporação automática, mas mantinham-se tensionados pelas histórias e avaliações críticas que essas mulheres constantemente reverberavam.

Os três casos nos ajudam a sugerir que os medicamentos, embora onipresentes no contexto da SCVZ, não contam com imagens fixas e estáticas. São, a todo tempo, testados, questionados, revistos, reposicionados e até evitados. Oscilam entre uma ponta positiva e outra negativa, permanecem - mas nunca indistintos - numa zona central, nebulosa e, sobretudo, ambígua. Cada criança, cada encontro clínico, cada arranjo farmacológico desperta uma série de novas reflexões por parte da mãe e do coletivo de mães de micro.

Soraya Fleischer é Doutora em Antropologia Social pela Universidade Federal do Rio Grande do Sul (UFRGS) e Professora Associada 2 da Universidade de Brasilia (UnB). Cocoordenadora do Coletivo de Antropologia e Saúde Coletiva (CASCA) e do Mundaréu - podcast de Antropologia. 
Ana Claudia de Camargoémestrandaem Antropologia Socialpela Universidade Federal de Santa Catarina (UFSC) e integrante do Coletivo de Antropologia e Saúde Coletiva (CASCA).

\section{REFERÊNCIAS}

Alves, R., \& Fleischer, S. (2019). “O que adianta conhecer muita gente e no fim das contas estar sempre só?” Os desafios da maternidade em tempos de Síndrome Congênita do Zika Vírus. Anthropológicas 29(2), 6-27. doi.org/10.51359/2525-5223.2018.239316

Anvisa (2020a). Boehringer Ingelheim Farmacêutica. Bula do Berotec (bromidrato de fenoterol). Itapecerica da Serra: [s.i.].

Anvisa (2020b). Abbott Laboratórios do Brasil LTDA. Bula do Depakene (valproato de sódio). Rio de Janeiro: [s.i.].

Bellacasa, M. (2010). Matters of care in technoscience: Assembling neglected things. Social Studies of Science, 41(1), 85-106. https://doi.org/10.1177/0306312710380301

Brasil. Ministério da Saúde, Secretaria de Vigilância em Saúde (2019). Boletim Epidemiológico 50. Brasília: Ministério da Saúde.

Brasil. Ministério da Saúde. Secretaria de Vigilância em Saúde. (2017) Virus Zika no Brasil: a resposta do SUS. Brasília: Ministério da Saúde.

Camargo, A. (2021). Antropologia dos medicamentos: o estado da arte das pesquisas no Brasil. Revista Textos Graduados, 7(2), 138-156. https://periodicos.unb.br/index.php/tg/article/view/38959

Castro, R. (2012). Antropologia dos medicamentos: uma revisão teórico-metodológica. Revista de Antropologia da UFSCar, 4(1), 146-175. https://doi.org/10.52426/rau.v4i1.68

Castro, B. \& Moreira, M. (2018). (Re)conhecendo suas casas: narrativas sobre a desospitalização de crianças com doenças de longa duração. Saúde Coletiva, 28(3), e280-322. https://doi.org/10.1590/ S0103-73312018280322

Fleischer, S. (2017). Segurar, Caminhar e Falar. Notas etnográficas sobre a experiência de uma mãe de micro no Recife/PE. Cadernos de Gênero e Diversidade, 3, 93-112. http://dx.doi.org/10.9771/cgd. v3i2.21983 
Fleischer, S. (2018). Cenas de microcefalia, de cuidado, de antropologia (Recife, setembro de 2017). Cadernos de Campo, 27(1), 118-131. https://doi.org/10.11606/issn.2316-9133.v27i1p118-131

Fleischer, S. (2012). Uso e circulação de medicamentos em um bairro popular urbano na Ceilândia, DF. Saúde e Sociedade, 212: 410-423. https://doi.org/10.1590/S0104-12902012000200014

Fleischer, S. (2020). Introdução. In S. Fleischer, \& F. Lima. (eds.). Micro (pp. 17-39). Brasília: Editora Athalaia.

Flores, L. (2016). "Na minha mão não morre": uma etnografia das ações judiciais de medicamentos (Dissertação de Mestrado). Programa de Pós-graduação em Antropologia, Universidade Federal do Paraná, Curitiba.

Foucault, M. (1979). O nascimento da clínica. São Paulo: Forense.

Fonseca, C. (2019). Crianças, seus cérebros... e além: reflexões em torno de uma ética feminista de pesquisa. Revista de Estudos Feministas, 27(2), e56169. https://doi.org/10.1590/ 1806-9584-2019v27n256169

Geest, S. V., \& Whyte, S. (2011). O encanto dos medicamentos: metáforas e metonímias. Sociedade e Cultura, 14(2), 457-472. https://www.revistas.ufg.br/fcs/article/view/17624

Martin, D.; Caccozi, A.; Macedo, T., \& Andreoli, S. (2012). Significado da busca de tratamento por mulheres com transtorno depressivo atendidas em serviço de saúde público. Interface, 16, 885-899. https://doi.org/10.1590/S1414-32832012000400003

Mattingly, C. (2014). Moral laboratories: family peril and the struggle for a good life. Oakland: California University Press.

Medley Farmacêutica. (2021). Bula do medicamento Zodel. Suzano: [s.i]. https://www.medley. com.br $/$ medicamentos $/$ bula $? \mathrm{id}=589 \mathrm{c} 8 \mathrm{bbc} 52765 \mathrm{e} 0010 \mathrm{faab} 5 \mathrm{~d} \& \mathrm{v}=0$

Mundaréu. (2020). A gente vai no boca a boca. [Podcast]. Mundaréu, 15 jun. Recuperado de: https://mundareu.labjor.unicamp.br/7-a-gente-vai-no-boca-a-boca/

Novas, C. (2006). The Political Economy of Hope: Patients' Organizations, Science and Biovalue. BioSocieties, 1, 289-305. https://doi.org/10.1017/S1745855206003024

Peirano, M. (2008). Etnografia ou a teoria vivida. Ponto Urbe, 2(2), 1-10. https://doi.org/10.4000/ pontourbe. 1890 .

Rabeharisoa, V. (2006). From representation to mediation: The shaping of collective mobilization on muscular dystrophy in France. Social Science \& Medicine, 62(3), 564-57. https://doi.org/10.1016/j. socscimed.2005.06.036 
Rios, C. (2019). Expert em seu próprio filho, expert em seu próprio mundo - reinventando a(s) expertise(s) sobre o autismo. In C. Rios, \& E. Fein. (Eds). Autismo em Tradução: Uma conversa intercultural sobre condições do espectro autista (pp. 231-257). Rio de Janeiro: Papéis Selvagens.

Scott, R.; Quadros, M.; Silva, A.; Lira, L.; Matos, S.; Souza, F., \& Saraiva, J. (2017). A Epidemia de Zika e as articulações das mães num campo tensionado entre feminismo, deficiência e cuidados. Cadernos de Gênero e Diversidade, 3, 73-92. http://dx.doi.org/10.9771/cgd.v3i2.22013

Scott, R; Lira, L; Matos, S; Souza, F.; Silva, A., \& Quadros, M. (2018). Itinerários terapêuticos, cuidados e atendimento na construção de ideias sobre maternidade e infância no contexto da Zika. Interface, 22, 673-684. https://doi.org/10.1590/1807-57622017.0425

Simas, A. (2020). Ciência, saúde e cuidado: Um estudo antropológico sobre a pesquisa clínica no contexto da epidemia do Zika (Recife-PE) (Monografia de Graduação). Departamento de Antropologia, Universidade de Brasília, Brasília.

Vitor, V. (2019). Uma tramitação legislativa da esperança: reflexões sobre a construção da causa coletiva como pauta legislativa em Política Nacional para Doenças Raras no Senado Federal. (Dissertação de Mestrado). Departamento de Antropologia, Universidade de Brasília, Brasília.

Valim, T. (2017). Um olhar antropológico sobre a sociabilidade de bebês nascidos com a Sindrome Congênita do Zika Virus em Recife/PE: "ele sente tudo o que a gente sente". (Monografia de Graduação). Departamento de Antropologia, Universidade de Brasília, Brasília.

Whyte, S.; Geest, S V., \& Hardon, A. (eds). (2002). Social Lives of Medicines. Cambridge: Cambridge University Press. 


\title{
BEROTEC, DEPAKENE E ZODEL: AMBIGUIDADES FARMACOLÓGICAS NO CON- TEXTO DA SÍNDROME CONGÊNITA DO VÍRUS ZIKA EM RECIFE/PE
}

Resumo: A síndrome congênita decorrente da infecção pelo vírus Zika (SCVZ) é uma condição de saúde com muitos sintomas e graus de deficiência nas crianças infectadas. Essa infância é perpassada intensamente pela biomedicina, seus profissionais e suas tecnologias, em especial hospitais e medicamentos. Com o objetivo mais amplo de conhecer as consequências a longo prazo que uma epidemia deixa, os medicamentos têm se revelado uma boa pista etnográfica no caso da SCVZ. Berotec, Depakene e Zodel, três medicamentos muito citados e usados por essas famílias da Grande Recife/PE, onde essa pesquisa foi realizada, servirão para conhecer os impactos da epidemia; apresentar algumas dessas interlocutoras; adentrar no contexto de convivência e cuidados diários com a SCVZ; e notar como essa presença farmacológica não é suave. Embora onipresentes nesse contexto epidemiológico, os medicamentos não contam com imagens fixas e estáticas e, a todo tempo, são testados, questionados, revistos, reposicionados e até evitados.

Palavras-chave: epidemia; síndrome congênita do vírus Zika; medicamentos.

\section{BEROTEC, DEPAKENE AND ZODEL: PHARMACOLOGICAL AMBIGUITIES IN THE CONTEXT OF THE ZIKA VIRUS CONGENITAL SYNDROME IN RECIFE/PE}

\begin{abstract}
Congenital syndrome due to Zika virus infection (SCVZ) is a health condition with many symptoms and degrees of disability within infected children. This childhood is intensely pervaded by biomedicine, its professionals and its technologies, especially hospitals and pharmaceuticals. With the broader goal of knowing the long-term consequences that an epidemic leaves, drugs have proved to be a good ethnographic shortcut in the case of the SCVZ. Berotec, Depakene and Zodel, three of the frequently drugs used by these families in the Greater Recife/PE, where this research was conducted, will be of great help to understand the impacts of the epidemic; present some of these interlocutors; to enter the context of daily care with SCVZ; and notice how this pharmacological presence is not smooth. Although omnipresent in this epidemiological milieu, these drugs do not have fixed and static images and, at all times, are tested, questioned, reviewed, repositioned and even avoided.
\end{abstract}

Keywords: epidemics; Zika virus congenital syndrome; pharmaceuticals.

RECEBIDO: $31 / 03 / 2021$

ACEITO: $19 / 07 / 2021$ 